\title{
Tegning som trædesten til at nærme os svære og tabubelagte emner i forskningsprojekter med børn
}

\section{Elisabeth Søndergaard (ES) \& Susanne Reventlow (SR)}

Institut for Folkesundhedsvidenskab, Københavns Universitet elisab@sund.ku.dk

Søndergaard, Elisabeth; Reventlow, Susanne (2018). 'Tegning som trædesten til at nærme os svære og tabubelagte emner i forskningsprojekter med børn ' i Tidsskrift for Forskning i Sygdom og Samfund, nr. 29, 147-171.

Studier af belastende socioøkonomiske forhold i barndommen peger på en sammenhæng mellem dette og en øget risiko for at udvikle sygdomme senere i livet. Forskning peger desuden på, at børn af syge forældre både er mere syge og mere ensomme end jæonaldrene med raske forældre. Sammenhængen støttes af studier, som viser, at børns sociale relationer har afgørende betydning både for oplevelsen af deres barndom og for deres aktuelle og senere sundhedsprofil. Med afsæe $i$ de sociale relationers betydning for børnenes sundhed har vi ønsket at undersøge, hoordan børn $i$ ressourcesvage familier oplever deres relationer og familieliv, men hvordan undersøger man det metodisk? Denne artikel viser gennem eksempler fra et feltarbejde blandt socioøkonomisk udsatte børnefamilier med en multisyg forælder på Lolland-Falster, hvordan tegning som metode kan være med til at facilitere samtaler om svære og tabubelagte emner med børn. Metodens styrker ligger dels $i$ den konkretiserende form, der er med til at materialisere tanker og følelser, dels $i$ måden den muliggør et fxllesskab mellem barn og forsker, der ofte er udfordret i etnografisk børneforskning. Støttet af tegningerne var børnene i stand til at give udtryk for følelser, stemninger og oplevelser, 
som indholdsmæssigt var vanskelige at sætte ord på, men som ikke på samme måde var svære at genkalde sig $i$ kroppen eller at tegne på papir. Bl.a. hjalp tegningerne med at illustrere et gennemgående ønske blandt de deltagende børn, der centrerer sig om normalitet, rutiner og stabilitet i familien. Artiklen understreger, at det er vigtigt, at tolkningen af det tegnede akkompagneres af feltarbejdets anden data og et velfunderet kontekstindblik.

Drawing as a stepping-stone to approach difficult and tabooed issues when doing research with children

Studies of disadvantaged socioeconomic conditions in childhood suggest a connection between this and an increased risk of developing diseases later in life. Furthermore, research indicates that children of ill parents are both more ill and lonelier than their peers with healthy parents. The correlation is supported by studies that show how children's social relations are vital for the experience of their childhood and for their current and future health profile. Based on the importance of social relations for children's health we wanted to investigate how children in resource-poor families experience their family life, but how do one study this? Through examples from a fieldwork among socio-economic disadvantaged young families with a parent with multiple diagnoses on Lolland-Falster this paper shows how drawing can be a method to facilitate conversations with children about difficult and tabooed issues. The method's strength lays in its way to materialize thoughts and feelings, and in its way to create a feeling of 'community' between the child and the researcher, which is often experienced as challenging in ethnographic research among children. Supported by the drawings, the children were able to express feelings, sentiments, and experiences which were difficult to articulate with words, but not in the same way difficult to recall in the body or to draw on paper. The drawings illustrated a common wish among the participating children, centered round normality, routines and stability within the family. We emphasize that it is important to include other data from the fieldwork when interpreting drawings and essential to have a solid contextual understanding of the field.

\section{Introduktion}

Studier af belastende socioøkonomiske forhold i barndommen peger på en sammenhæng mellem dette og en øget risiko for at udvikle sygdomme senere i livet (Anda et al., 2006; Graham, 2007). Samtidig indikerer nye projekter om multisygdom, at der er en association mellem voksne patienter med flere samtidige diagnoser og det at have oplevet sin barndom som vanskelig (Tomasdottir et al., 2015). 
Forskning peger desuden på, at børn af forældre med dårligt helbred ikke bare er mere syge, men også mere ensomme end børn med raske forældre (Campo et al., 2007). Denne sammenhæng understøttes af undersøgelser, der viser, at børns sociale relationer er afgørende både for oplevelsen af deres barndoms og for deres nuværende og fremtidige sundhedsprofil (Kirkengen, 2005). Således skriver artiklen sig ind i en samfundsmæssig og politisk rammesætning med fokus på forebyggelse og tidlig opsporing af børn og unge, der vokser op i udsatte familier (Socialstyrelsen 2018). Artiklen går undersøgende til dette ved at have særligt blik for børns oplevelser med relationer og familieliv.

Historisk har antropologiske studier af slægtskab og familie haft tendens til at fokusere på de positive aspekter herved. Sahlins berømte beskrivelse af et »Mutuality of Being « præsenterer slægtskab som en dybtfølt, forenet enhed, men som italesat af bl.a., Peletz (Peletz, 2001), Lambek (Lambek, 2011) og nyligen i en dansk kontekst af Mogensen og Olwig (Mogensen \& Olwig, 2013) indeholder familie- og slægtskabsrelationer imidlertid også ambivalente og negative kvaliteter. At være en del af en familie spiller en central rolle i vores selvforståelse, men det er en kompleks størrelse. Det er en metafor for stærke og varme relationer, men i praksis kan familieforhold være problematiske, krævende og forbundet med tvetydige følelser.

Børn, der vokser op i familier med sociale udfordringer eller sygdomsproblematikker, vil ofte efter bedste evne forsøge at skjule dette, og gøre hvad de kan for at opretholde et idealiseret billede af deres familie udadtil (Werner \& Malterud, 2016). Det kan derfor være problematisk at adressere og vanskeligt at tale med børn om i forskningsøjemed.

Fra august til december 2015 gennemførte førsteforfatter, ES, første fase af et todelt feltarbejde blandt socioøkonomisk udsatte børnefamilier med en multisyg forælder på Lolland-Falster. Fokus var på sociale relationer og netværk i og omkring familierne med henblik på at få mere viden om, hvordan børns trivsel og sundhed formes i konteksten af familien. Sammen med feltarbejdets anden del, som bestod af opfølgende besøg hos familierne i foråret 2017, udgør dette den kvalitative del af et mixed methods-ph.d.-studie, hvis data denne artikel bygger på. Feltarbejderne fulgte seks case familier og deres udvidede netværk (Burawoy, 1998), og det er dataindsamlingen blandt børnene i de seks familier, som artiklen her fokuserer på. Mere specifikt er det erfaringer med at kombinere tegning og samtale som forskningsmetode i arbejdet med børn, vi vil præsentere og diskutere. 
Efter en kort introduktion til den generelle udvikling indenfor børneforskning og visuelle forskningsmetoder som felt, vil artiklen udforske anvendelsen af tegning kombineret med samtale til at få indsigt $\mathrm{i}$ børns oplevelse af familieliv og relationer, når disse udfoldes i en hverdag, hvor forældres sygdom spiller en gennemgående rolle. Med udgangspunkt i eget projekt og delresultater vil vi vise, hvordan denne type metode genererede data, som uddybede den empiriske viden og forståelse for felten. Det er vigtigt, fordi metoden derved understøtter et aktørorienteret perspektiv, der nuancerer vores forståelse af børnenes livsverden. Slutteligt vil vi reflektere over de udfordringer, der eksisterer ved tegning som metode i børneforskning.

\section{Udviklingen inden for børneforskning og visuelle forskningsmetoder}

Inden for samfundsvidenskabelig børneforskning er der stigende interesse i at få indsigt i børneperspektiver på forskellige forhold i børns hverdag (Nielsen, 2012). Projekter har bl.a. set på børns oplevelser af, hvad der er godt eller svært i daginstitutionen eller skolen (Kragh-Müller \& Isbell, 2011), undersøgt børneperspektiver på det gode skolemåltid (Bruselius-Jensen, 2011) og gode ideer til skoleindretning (Clark, 2010), børns erfaringer med mobning (Søndergaard, 2013) eller med en sygdomsepidemi i eget lokalsamfund (Denis-Ramirez, Sørensen, \& Skovdal, 2017), kronisk syge børns tolkninger af egne symptomer (Gabriels, Wamboldt, McCormick, Adams, \& McTaggart, 2000; Stafstrom, Goldenholz, \& Dulli, 2005) og børns oplevelser af vigtige situationer i hjemmet, institutionen eller skolen (Müller, 1999; Nielsen, 1999). I alle de nævnte undersøgelser har forskerne talt med og i forskellig udstrækning observeret børnene i deres hverdag, og endelig har de inviteret børnene til at tegne, i forhold til de emner undersøgelserne vedrørte, ligesom det var fremgangsmåden i nærværende projekt.

Hvor man tidligere inkluderede børns perspektiver i forskningsprojekter om børn, stræbes der i dag i langt højere grad efter at inddrage børneperspektiver i projekter med eller for børn (Darbyshire, MacDougall, \& Schiller, 2005; Mayall, 2000). Selvom de to scenarier lyder ens, er der en grundlæggende fænomenologisk forskel i måden, hvorpå de to tilgange forstår og behandler barnets væren i verden. I forskningsregi er børn historisk blevet betragtet som inkompetente, upålidelige og ufuldstændige (Barker \& Weller, 2003). Forskning om børn var der- 
for en proces, hvor en voksen rekonstruerede barnets erfaringer og forståelser af verden. Selvom tilgangen var børnecentreret, lå der iboende i den voksnes repræsentation af barnet en uomtvistelig objektivisering. I kontrast hertil betragtes børn i dag i langt højere grad som handlende subjekter, der er 'eksperter' på deres eget liv og som med egne ord, stemningsbeskrivelser og/eller tegninger er i stand til at udtrykke sig indsigts- og meningsfuldt herom (Fargas Malet, 2010; Sommer, Pramling Samuelsson, \& Hundeide, 2010). Det ændrer måden, hvorpå børn opfattes; dels som individer, dels som forskningsfelt, og det betyder, at barndommen som fænomen ikke kan studeres som et isoleret felt, men derimod betragtes som værende socialt og kulturelt konstrueret (James, Jenks, \& Prout, 1999).

Paradigmeskifte indenfor børneforskning har samtidigt faciliteret en parallel udvikling af nye datagenereringsmetoder, som den stigende udbredelse af visuelle metoder er et eksempel på (Christensen \& James, 2000). Udviklingen skyldes bl.a. en bredt accepteret opfattelse af, at brugen af visuelle metoder, som fx videodagbøger, kortlægnings-øvelser, photo-voice eller tegning, mindsker de krav, der stilles til informantens sproglige kompetencer, og at en non-verbal tilgang således kan facilitere en anden vej til informanters livsverdener i form af følelser, tanker og stemninger (Cox, 2005; Jolley, 2010; Koppitz, 1968).

Visuelle tilgange understøtter således deltagelsen af - såvel som formidlingen til - personer, som enten ikke er i stand til eller ikke er trygge ved at formulere sig sprogligt (Wang \& Burris, 1997). Det er samtidigt blevet foreslået, at visse informantgrupper, som fx børn og teenagere, i højere grad er komfortable ved at deltage i forskningsprojekter gennem visuelle repræsentationsformer, fordi disse minder om aktiviteter fra deres hverdag (Clark, 1999; Croghan, Griffin, Hunter, \& Phoenix, 2008). I tråd hermed er det blevet fremført, at anvendelsen af visuelle metoder muliggør en mere aktiv deltagelse fra disse grupper og endeligt, at det faciliterer adgangen til mere nuanceret data sammenlignet med fx en traditionel interviewsituation (Mauthner, 1997).

\section{Tegning som metode inden for børneforskning}

Når et barn tegner, er råmaterialet noget barnet føler, oplever, kender, har erfaret eller kan forestille sig (Nielsen, 2012). Børns tegninger kan derfor betragtes som artikulationer af endnu ikke tematiserede følelser, oplevelser og betydninger (Bastrup-Madsen, 2001; Funch, 1996), men tegningens udtryk er samtidigt påvirket af barnets tegnefærdigheder og abstraktionsniveau og af barnets kendskab 
til kulturelle visuelle koder fra dets omverden. Børn lærer at anvende kulturelle visuelle koder i deres udtryksformer, både når de tegner hjemme og i institutionsregi, men også når de på anden måde møder og anvender visuelle kulturelle udtryksformer, som bl.a. omfatter hverdagssprog, kropslige udtryk og mediebilleder (Nielsen, 2012). Desuden er børns tegninger påvirket, af den sammenhæng de laves i, hvilke instrukser der er forbundet med aktiviteten, og ikke mindst hvilken relation barnet har til den, der giver instrukserne. Børnetegninger kan fremstille udvalgte oplevelser fra barnets livsverden og vise noget om, hvad der er vigtigt for barnet i disse oplevelser og erfaringer, og hvad barnet har lagt mærke til, husker og finder væsentligt i tegnesituationen. Gennem tegning kan barnet derfor udtrykke noget følelsesmæssigt og oplevet betydningsfuldt, der endnu ikke er hverken kategoriseret eller verbaliseret (Frederiksen, Gundelach, \& Nielsen, 2014).

Generelt behandles børns tegninger som data, der har karakter af reference. Dvs. at tegningerne betragtes som tegn eller symboler, der fortæller om og henviser til noget, der har lagret sig i barnet. Som konsekvens heraf anvendes tegnemetoden ofte i kombination med en uddybning fra barnets side, enten skriftlig eller mundtlig, og det var ligeledes fremgangsmåden i dette projekt. Vi talte både om tegningen undervejs, og efter at den havde taget form. Det gav barnet mulighed for at forholde sig til det tegnede og til at forklare sig yderligere (Driessnack \& Furukawa, 2012). Teknikken støttede barnet i at genkalde sig bestemte oplevelser eller stemninger, og metoden giver derfor en anden indsigt i de tolkninger og meninger, barnet forbinder med den tegnede situation, end den som kan opnås gennem interview eller spørgeskemabesvarelser (Butler, 1995; Driessnack \& Furukawa, 2012; Gross, Hayne, \& Drury, 2009).

Fordi børns tegninger kan fungere som en nonverbal trædesten til børns erfarings- og følelsesverden (Cox, 2005; Jolley, 2010; Koppitz, 1968), kan samtaler om børns familietegninger forventes at give et kendskab til børns relationelle oplevelser inden for rammerne af deres familie (Cherney, Seiwert, Dickey, \& Flichtbeil, 2006; Gernhardt, Rübeling, \& Keller, 2013; La Voy, 2001). I dette projekt er disse rammer bl.a. formet af, at minimum den ene forælder var multimorbid. I overensstemmelse med udbredte definitioner af begrebet dækker det over en tilstand, hvor personen lider af to eller flere samtidige, kroniske sygdomme (Diederichs C, Berger K, \& Bartels DB, 2011). Kombinationen af sygdomme varierede mellem familierne og spændte bl.a. over psykiske sygdomme, KOL, alvorlige former for gigt og forskellige misbrugstilstande. Den gennemgående fællesnævner var, at sygdommene fyldte i hverdagen og dermed var med til at slå tonen an for familiernes hverdagsliv. Desuden var familierne karakteriserede ved at være socioøko- 
nomisk udsatte i kraft af forældrenes lave uddannelsesniveau og løse tilknytning til arbejdsmarkedet. Det interessante i forhold til tegning som metode er, at den viste sig at være særdeles brugbar til at understøtte samtaler med børnene om svære og tabuiserede emmer, på trods af at årsagerne til børnenes bekymringer var forskelligartede.

\section{Metode og analyse}

Ph.d.-projektet, som denne artikel tager sit udspring i, har et mixed methods-projektdesign, som betyder, at der anvendes en kombination af metoder, bl.a. en interaktiv proces mellem deltagerobservationer, samtaler, interviews og børnetegninger. Det todelte feltarbejde fulgte familiemedlemmerne i de sociale sammenhænge, de indgik i over tid (Gulløv \& Højlund, 2003). Formålet var at få indsigt i de prioriteringer og logikker, der motiverer til handling og giver mening lokalt, men som sjældent lader sig indfange gennem eksplicitte udtalelser (Hastrup, 1992). I projektets første fase (aug. - nov. 2015) gennemførtes et fire måneder feltarbejde blandt 6 udvalgte case familier med børn i alderen 6-12 år og familiernes udvidede netværk. I perioden fokuserede ES på at have en åben observationstilgang med udgangspunkt i børnenes hverdag (Hammersley, 2007). Hun var sammen med børnene hjemme i familierne, når de udførte deres daglige rutiner eller lavede ingenting, samt til de aktiviteter børnene deltog i udenfor hjemmet (Gulløv \& Højlund, 2003). I den indledende fase blev observationerne kontinuerligt fulgt op med samtaler for at undersøge betydningen af det observerede (Hastrup, Rubow, \& Tjørnhøj-Thomsen, 2011). Efter passager med deltagerobservation blev deskriptive feltnoter nedskrevet, og endeligt blev semistrukturerede interviews gennemført med børnenes forældre og nøglepersoner i børnenes netværk (Som fx lærer, håndboldtræner og venner af familie). Baseret på resultaterne fra første feltarbejde blev der lavet en detaljeret plan for fase to, der løb fra februar til april 2017. Anden del bestod af et fokuseret feltarbejde (Rubow, 2003). Semistrukturerede interviews gennemførtes på ny med forældre og for første gang med børnene. Til at understøtte børneinterviewene og for at afmystificere interviewsituation tog vi udgangspunkt i illustrative, laminerede billeder af forskellige hverdagssituationer i danske børneliv (Harper, 2002). Temaerne i interviewene med børnene indeholdt bl.a. beskrivelser af deres familie og venskaber samt deres egen skildring af deres hverdag. I forhold til børnenes sociale relationer og netværk fokuserede interviewerne på, hvem børnene selv anså for at være tæt på eller betydningsfulde 
i deres dagligdag og deres erfaringer og oplevelser med disse. Endelig gennemførtes draw-and-talk-øvelser med projektets børneinformanter (Wright, 2007). Draw-and-talk-øvelserne gennemførtes i to set-ups; hjemme hos familierne og som to gruppe-sessioner på et familieværksted, hvor en mindre gruppe af børn, der kendte hinanden godt, sad sammen, mens de tegnede og fortalte. I begge scenarier bestod øvelsen i, at børnene blev bedt om at tegne først en god situation i deres familie og dernæst en svær situation i deres familie. Virkningen af på denne måde at bede børn tage stilling til oppositionelle situationer er andetsteds blevet beskrevet som en mulighed for de deltagende børn til at præcisere deres oplevelse med en meningstung situation (Maxwell, 2006). På den måde understøttes børnene $i$ at kommunikere et mere detaljeret perspektiv, sammenlignet med hvis de kun var blevet bedt om at tegne den ene af de to situationer. Målet var at udforske en så bred som mulig vifte af betydninger, i forhold til den hverdag og det familieliv som mine børneinformanter oplevede, og brugen af modsætninger begunstigede det formål. Samtidigt kræver den dikotomiske opsætning en bevidsthed om, at øvelsen kan fremme en kunstig polarisering af det undersøgte emne; i dette tilfælde børnenes oplevelse af forskellige familiesituationer. Grænsefladerne risikerer derved at blive trukket skarpere op end virkelighedens kontinuum af gode og svære familiesituationer. Det aspekt er med til at understrege vigtigheden af at kombinere tegnemetoden med andre kvalitative forskningsmetoder for således at have et velforankret indblik i den kontekst, hvori øvelsen gennemføres.

Både undervejs, mens tegningerne blev til, og efter at de lå klar, talte vi om den fortælling, barnet gerne ville kommunikere med tegningerne, det konkrette motiv barnet forsøgte at tegne og det endelige resultat, som figurerede på papiret. ES spurgte fx løbende ind til, hvad det var, der gjorde situationen god eller svær, og det var børnene i forskelligt omfang og på forskelligt detaljeniveau i stand til at sætte ord på.

Efter at øvelsen var gennemført med alle børnene, blev en indholdsanalyse brugt til at analysere og kategorisere børnenes tegninger sammen med transskriptionerne af de uddybende samtaler, vi havde, i forbindelse med at tegningerne blev til. Dvs. at de to forskellige former for materiale - tegninger og samtaler - bliver opfattet som én dataenhed. Indholdsanalyse eller content analysis, som metoden i højere grad kendes under, er en procedure, hvor det, vha. identificeringen af udvalgte tematikker i materialet, er muligt at gå fra det specifikke til det generelle. Det muliggør en systematisk fremgangsmåde at arbejde med forskelligartet data på, herunder nedskreven og visuel empiri (Elo \& Kyngäs, 2008; Krippendorff, 2004). I første omgang gennemgik artiklens førsteforfatter tegnin- 
gerne og de mundtlige uddybninger heraf og udviklede på den baggrund en tematiskoversigt, der karakterisede data, herunder: afbildede individer (barnet selv såvel som andre), lokaliteter, aktiviteter, udtrykte følelser, stemninger og børnenes udtrykte overvejelser og tanker i forbindelse med øvelsen. Desuden blev alle transskriptioner af interviewene med børnene, som gik forud for tegneøvelsen, samt de feltnoter der akkompagnerede selve øvelsen, gennemlæst af begge artiklens forfattere med et fokus på de identificerede tematiske kategorier. Efterfølgende mødtes forfatterne for at gennemgå resultaterne og identificere de temaer og subtemaer, som slutteligt udgjorde de endelige fund.

\section{Roller og relationer mellem forsker og børneinformanter}

Projektet havde fokus på at undersøge roller og relationer i udsatte børnefamilier. Imidlertid er det samtidigt vigtigt at se nærmere på de roller og relationer, som forskeren indgik i, fik tildelt og tog under gennemførelsen af projektet (Reventlow \& Tulinius, 2005) - her med særligt fokus på, hvad det betød for tegning som metode i arbejdet med børneinformanter.

Projektet har indhentet samtykke fra alle studiets deltagende børn, samt børnenes forældre, men hvordan sikrer man sig, at børn forstår, hvad det egentlig betyder at deltage i et forskningsprojekt? Til børnene sammenlignede ES det med, når de havde lektier for i skolen. Hun havde en rigtig stor opgave for, som hun bedst kunne besvare, hvis børnene hjalp hende med at forstå, hvordan det var at være barn. De var eksperterne! Børnene blev endvidere forsikret om, at hun ikke ville fortælle nogen - heller ikke deres forældre - hvad de fortalte hende, og at hun, når hun skrev om dem i sin opgave, ville bruge andre navne. Det førte bl.a. til flere snakke om, hvad de så skulle kaldes. En af pigerne ville gerne have garanti for, at hun ville blive kaldt Petra ligesom naboens kat, mens en af drengene derimod ville loves, at han ikke blev gengivet som Patrick - den dummeste dreng i hans klasse!

Projektet ønskede at se på hele familier, og adgangen til børneinformanterne gik gennem deres forældre. Det betød, at børn, hvis forældre ikke ønskede at deltage i projektet, var afskåret for muligheden, og det skal selvfølgelig lede til overvejelser omkring fraværet af de stemmer, vi ikke har hørt (Jamieson, Simpson, \& Lewis 2011). Familierne, som ikke ønskede at deltage, adskilte sig ikke, fra de der 
deltog, i forhold til sygdomme og socioøkonomisk profil, men angav ikke at have tid eller overskud til at engagere sig i projektet. Kan man antage, at hverdagslivet i netop de familier har været endnu mere presset set fra børnehøjde? For de børn, hvis familie deltog, betød rekrutteringsfaconen imidlertid, at alle havde oplevelsen af, at ES fra dag ét bogstaveligt talt var inviteret indenfor i varmen hjemme hos dem. Tegneøvelsen lå sidst $\mathrm{i}$ feltarbejdet og forud for det, var der gået måneder, hvor ES løbende havde været på besøg i hjemmet, talt gentagende gange med deres forældre, og for alle børnenes vedkommende havde hun haft 'alene-tid' med dem, hvor de havde vist hende deres værelse, deres yndlingslegetøj eller trampolinen i haven. For alle børnene galt det ligeledes, at de inden tegneøvelsen havde gennemført et interview med ES.

Etnografisk forskning med børn er udfordrende, bl.a. fordi gængse kulturelt funderede barn/voksen-roller er udviskede og dermed også de typer af interaktioner og regelsæt, der normalvis knytter sig hertil (Mandell, 1991; Fine and Sandstrom, 1988; Pollard and Filer, 1996; Mayall, 2000).

Når en fremmed voksen begynder at komme i dit hjem, er til stede uden tydeligt formål og stiller pudsige spørgsmål, ligner det ikke umiddelbart de voksenroller, som børn normalvis kender, og derfor kan det være vanskeligt for et barn at give en forsker et passende mærkat (Christensen 2004). Så hvad var ES for en slags voksen for børnene? Mest af alt virkede det til, at børnene syntes, hun var 'en mærkelig fisk', der netop faldt mellem forskellige kategorier af roller. Hen ad vejen opsøgte børnene i stigende grad ES på eget initiativ og gav udtryk for, at de syntes, at det var hyggeligt at være sammen. Måske skyldes det, at ES i hele forløbet bestræbte sig på at vise, at hun ville deres samvær og anstrengte sig for at gå til relationen med stor lydhørhed for børnenes ønsker og grænser. Ikke mindst i de situationer hvor børnene ikke var interesseret i hendes selskab.

Som vi vil vise i de næste afsnit, skabte tegneøvelsen et trygt samtalerum, hvor det var mindre fremtrædende, at der ikke var veletablerede rutiner for, hvordan vi som barn og forsker var sammen, og som var med til at gøre, at børnene åbnede op for samtaleemne, som feltarbejdets andre dele ikke på samme måde havde ført til. Det betød også, at ES turde stille spørgsmål, som hun indtil da ikke synes havde været etiske eller legitime at stille. På den måde gav metoden både nogle andre og nogle ekstra lag af viden. For at bevare autenticiteten er beskrivelserne gengivet i førsteperson. 


\section{Tegning som trædesten til at nærme sig svære emner}

Når jeg bad mine børneinformanter om at tegne en god eller en svær situation i deres familie, spurgte de ind til, hvad jeg mere præcist mente med det. Jeg uddybede, at den gode situation var den bedste situation, de kunne forestille sig med deres familie, og at en svær situation var en vanskelig situation, som havde været irriterende eller gjort dem ked af det. I begge tilfælde forklarede jeg, at det kunne være en situation, som de tænkte tilbage på, eller en situation som de forestillede sig. Med udgangspunkt i to tegninger vil vi i det følgende vise, hvordan metoden åbnede op for fortællingen, og hvordan den støttede børnene i at artikulere perspektiver, som det grundet emnernes tyngde og kompleksitet var vanskeligt for dem at få hul på og formulere med ord.

\section{Hvor mon jeg skal være næste weekend?}

Af alle de tegninger der blev lavet i løbet af feltarbejderne, var Simone den, der brugte længst tid på projektet. Simone var den eneste, der ikke lavede øvelsen i selskab med andre børn, og hun brugte timer, gik til og fra, talte meget om sine overvejelser og valg, tilføjede løbende elementer og kom med uddybende forklaringer undervejs. Meget af tiden sad hun også bare lænet ind over papiret og tænkte. Simone lavede en tegning af sig selv og sin mor, der ser X-Factor i fjernsynet fredag aften. Simones mor er ikke på billedet, men hun er vigtig i den fortælling, som Simone gerne ville male frem. Da jeg spørger ind til det, forklarer Simone, at mor måske er ude at hente slikket i køkkenet, og at det er derfor hun ikke er med på tegningen. Simone bor alene med sin mor i et mindre rækkehus. Da jeg besøgte familien i anden fase af feltarbejdet, var de netop flyttet ind, for siden sidst var konflikterne med de gamle naboer taget til, og Simones mor havde endt med at beslutte sig for at flytte. Det var ikke første gang, at den situation opstod. Simone havde ikke været nødt til at skiftet skole, men mange andre aspekter af hendes dagligdag havde fået en rystetur og var stadig i processen med at lande. Når Simone var sammen med sin far, ca. en weekend hver måned, plejede de at være ved hendes farforældre, men på det tidspunkt, hvor Simone lavede tegningen, talte hendes far og hans forældre ikke sammen, og derfor var Simone usikker på, hvor de skulle være næste weekend, hvor det var planlagt, at hun skulle se ham. Faderens og bedsteforældrenes konflikt betød også, at Simone var kommet i tvivl om, hvorvidt farfar og farmor stadig var en del af hendes familie. Begge dele var i sagens natur noget, der bekymrede Simone, og som hun havde svært ved 
rigtigt at forstå og vide, hvordan hun skulle agere i forhold til. Under tegneøvelsen løb hun flere gange hen og spurgte sin mor, som var til stede i huset, hvor hun troede, hun og faderen skulle være den følgende weekend, og gentagende gange sagde hun til mig og til sig selv, "Jeg må jo bare vente og se". Vi kom til at tale om det, fordi Simone jo så ikke ville være hjemme og se X-Factor med sin mor, ligesom hun havde tegnet på tegningen. Simone elskede fredagene med X-Factor. Jeg spurgte, hvad det var, der gjorde dem så gode, og hun fortalte, hvordan de altid var nede at købe slik, og så sad de der i sofaen bare hende og mor, og hun måtte være længe oppe. Hun kom også i tanke om, at hun gerne ville være pæn ligesom pigerne på scenen, og så tegnede hun en sløjfe i sit hår. Hun smilede fra øre til øre, mens hun fortalte om det, og det var tydeligvis en rigtig rar situation for hende at tænke på og tale om. På baggrund af mit kendskab til familien, ved jeg, at Simones mor gjorde alt, hvad hun kunne, for at opfylde Simones ønsker. Selvom pengene var små, så bugnede Simones værelse af legetøj, og hun var netop blevet skrevet op til rideundervisning, som hun længe havde plaget om. Jeg ved imidlertid også, at Simones mor i perioder var så belastet af sine depressioner, at hun havde svært ved at udfylde moderrollen, og at hun i sådanne perioder kunne have vanskeligt selv ved hverdagsting som $\mathrm{fx}$ at se TV med sin datter.

\section{Forestillingen om samværet med en voldelig far fra en 9-årigs perspektiv}

Emily kommer fra en familie med voldsomme konflikter mellem mor og far og med en forhistorie, der inkluderer alkohol og fysisk misbrug. I dag er forældrene skilt, og al kommunikation går gennem socialforvaltningen. Tegningen som Emily har lavet, viser hende selv, der sidder mellem sin far og sin mor, mens de alle tre tegner. De er i gang med en konkurrence, og tallene over deres hoveder viser, hvem der vandt, og hvem der blev nummer to og tre. Emily kom ved et uheld til at tegne sit eget øje helt sort så for at rede tegningen, gav hun dem alle tre solbriller på. Det er ikke juleaften, forklarer hun mig, men pigen har lige pakket en stor gave ind til hele sin familie, og det er derfor, der er et juletræ og pakker. Emily har også tegnet en enhjørning, fordi hun rigtig godt kan lide heste. Jeg ved, at Emily ofte tegner og laver perleplader med sin mor og Sabrina, som er Emilys lillesøster. Jeg har selv deltaget flere gange, familiens hjem er udstillingsplads for pigernes kreationer, og alle stuens vandrette flader er dækket af farverige perleplader, tegninger og små voksfigurer. På tegningen af en god situation i sin familie, har hun 
imidlertid skiftet lillesøster ud med sin far. På det tidspunkt, hvor Emily laver tegningen, har hun ikke været sammen med sin far i 7 måneder. Emily overværede en voldsepisode mellem faderen og hans daværende kæreste, som bl.a. betød, at faderen fik suspenderet retten til at se Emily, men inden længe skal de starte langsomt op med overvågede besøg, og mens Emily tegner stjerne på juletræet, fortæller hun mig stille, at hun glæder sig. Hun vil gerne, at de starter med at være hjemme ved mor og fx tegne, ligesom hun fint har illustreret på billedet. Det er første gang, jeg hører hende udtrykke sig sådan, men det er imidlertid ikke svært at forstå, at det kan være en vanskelig følelse - både at have og at tale højt om hjemme ved moderen, der dagligt taler dårligt om Emilys far. På baggrund af mine interviews med moderen og kendskab til familien, har jeg svært ved at forestille mig, at Emilys ønske kan blive virkelighed, og det tror jeg faktisk også godt, at Emily ved. Imidlertid ændrer det ikke ved, at det er den situation, hun vælger at tegne. Hun nærmer sig imidlertid sin egen skepsis ved at sige, at det måske var bedre, hvis hun og far tog i Zoologisk Have.

\section{Længslen efter normalitet, stabilitet og dagligdagsting}

Gennem stakken af tegninger, der afbilleder en god situation i projektets børneinformanters familier, løber et tema, der handler om normalitet, stabilitet og dagligdagsting. Det er situationer så som at spille ludo sammen, at spise aftensmad sammen, at sidde sammen i sofaen og se fjernsyn eller at tegne sammen, der går igen. Det er således billeder af hverdag, gentagelser og ro, som er gennemgående for de gode situationer.

Børnene har i høj grad tegnet en følelse, en stemning eller en oplevelse, som indholdsmæssigt er svær at sætte ord på, men som ikke er svær at genkalde sig i kroppen eller at tegne. I tegningerne har børnene illustreret oplevelser og fortællinger og derigennem artikuleret følelser, relationer og situationer. Fra at have en sanselig og flydende form bliver disse i tegningens udtryk fastholdt, og derved fungerer tegningen som et redskab til sammen at nærme os emner, som ellers ville forblive usagte og uopdagede. Tegningen gør således noget alene i kraft af dens materialitet.

En tegnings mening er ikke på samme måde som det talte ord 'hugget i sten', og derfor kan det at tegne være en mindre skræmmende aktivitet for børnene at indgå i sammenlignet med fx et interview. Som eksemplerne viser, kan tegningen fungere som trædesten til i fællesskab mellem barn og forsker at nærme os svære 
og tabubelagte emner. Netop fordi tegninger er åbne for en række fortolkninger og kræver forklaring, uddybning og kendskab til konteksten for at kunne forstå det specifikke budskab, er det et oplagt redskab til at nærme sig følsomme emner såsom problematiske familieforhold eller forældres sygdom. Desuden viste det sig, at tegneøvelsens rammer var åbne nok til, at børnene tegnede og talte om situationer, der var vigtige for lige netop dem, samtidigt med at rammerne var guidende nok til, at de udefinerede roller mellem barn og forsker ikke var en hæmsko.

\section{Ikke alle børn synes, det er sjovt at tegne}

For hovedparten af projektets børneinformanter var aktiviteten en stimulerende og sjov øvelse. De var spændte på at komme i gang, og da de fik et ark papir og tuscher udleveret, brugte de tid på at bestemme sig for, hvad det var, de ville tegne. De diskuterede valg af mulige situationer højt med sig selv og stillede uddybende spørgsmål i forhold til, hvilke "regler" der galte, og hvad der mere præcist mentes med en god og en svær situation. Efterfølgende brugte børnene betragtelig tid på at få tegningerne tegnet og på at få dem til se ud, som de gerne ville have dem. De kommenterede løbende ikke kun på indholdet af det tegnede, men også på deres evner - eller oplevede mangel på samme - til at få stregerne på papiret til at stemme overens med deres idé. Men enkelte børn brød sig ikke om øvelsen. En efterlod papiret blankt, en brugte meget kort tid på sine tegninger, og flere tegnede noget andet, end det opgaven gik ud på. (Eks. Må jeg godt tegne en dinosaur?). Det kan der være flere årsager til. Måske skyldes børnenes manglende lyst til at tegne en følelse af ikke at være god nok til disciplinen eller til at kunne portrættere det, de gerne ville afbillede, realistisk nok (Einarsdottir, Dockett, \& Perry, 2009). Det er også vigtigt at overveje, at børnene muligvis ikke havde lyst til eller ikke var trygge ved at tegne, det jeg bad dem om. Gennemgående havde børnene flest udfordringer med at skulle beslutte sig for en svær situation og efterfølgende at få den ned på papir. Man må derfor også nøje overveje under hvilke forudsætninger, man som forsker kan forvente, at børn kan eller vil være kritiske overfor deres familie (Jamieson, Simpson, \& Lewis 2011).

At bede børn om at fokusere på en svær situation i deres familie kan meget vel associere til vanskelige følelser, og for Marc var opgaven decideret ubehagelig. Ifølge Alderson er det altid bidende nødvendigt at være åben og reflekterende over for sensitive situationer (Alderson, 1995) og nøje overveje, hvordan de aktivi- 
teter, man som forsker sætter i gang, laver ringe i vandet og kan have konsekvenser også uden for rammerne af forskningsprojektet.

I førnævnte situation blev en lille dreng ked af det over at mindes sin mors indlæggelse året før. Marc havde været rigtig bange og bekymret for, om hans mor skulle dø. Efterfølgende brugte både moderen og ES meget tid på at forklare, at hans reaktion var helt naturligt, og at det var en meget, meget fin tegning, som han havde lavet. ES takkede inderligt for hans mod til at tegne og fortælle om det, men alligevel efterlod episoden et klart indtryk af, at Marc gerne ville have været episoden foruden. Den havde sat gang i følelser, som var ubehagelige for ham, og måske var han kommet til at kommunikere mere, end han egentlig havde lyst til at dele.

Uanset den bagvedliggende årsag til at enkelte af børneinformanterne ikke deltog i tegneøvelsen, så gjorde det artiklens forfattere opmærksomme på, at ikke alle børn er vilde med at tegne, og at børn, ligesom voksne, har forskellige kommunikative præferencer. Den erfaring var med til at understrege styrken ved et mixed method-design i projekter, hvor formålet er at få en bred indsigt i et meningstungt emne som forståelse af livet som barn i en socioøkonomisk udsat familie med en multisyg forælder.

\section{Tolkning af tegninger kræver et velfunderet kontekstindblik for at undgå fejlfortolkning}

Samtidig med en stigende anvendelse af visuelle metoder har fulgt en erkendelse af, at brugen af visuelle forskningsmetoder ikke står uden potentielle faldgrupper. Fx har der været skarp kritik af anvendelsen af visuelle metoder, når disse bliver tolket som neutrale refleksioner af virkeligheden og således glemmer kontekst, afsenderpositionering og forskerrolle, der er af ligeså afgørende betydning her som inden for alle andre forskningsmetoder (Clifford, 1986; Pink, 2005).

Størstedelen af børnetegningerne fra projektet giver et andet umiddelbart indtryk, når de står alene, end den indsigt vi opnåede, når tegningernes mening blev analyseret i sammenhæng med feltarbejdets andre typer data. Isoleret set er det fx oplagt at tilskrive kirken på Julies tegning en fremtrædende rolle, som den figurerer tronende, farverig og detaljeret på papirets højre halvdel. På baggrund af vores samtale under fremstillingen af tegningen og med det kenskab til familien, som feltarbejdets andre dele bidrog med, er det imidlertid klart, at kirken på Julies 
tegning udelukkende agerer statist til at nå til det, som Julie vil fortælle. Nemlig at Julie hver uge sammen med sin mor passerer den på vej til det familieværksted, som udgør den bedste situation, Julie kan komme i tanke om med sin familie. Kirken er således uden betydning i traditionel symbolforstand, men fuld af betydning som "løftestang" til at facilitere en samtale om, hvordan familieværkstedet med dets ugentlige tilbagevenden, dets faste rutiner omkring aftensmåltidet og ikke mindst det frirum fra en hverdag med meget kaos, som møderne giver Julie, er vigtige for hende.

Tegningen er således et eksempel på, at afbildningerne ikke kan analyseres adskilt fra projektets andet data. De skal derimod forstås i sammenhæng med de uddybende forklaringer, som børnene løbende gav undervejs, og på baggrund af den kontekstforståelse feltarbejdets andre elementer bidrog med. Tegninger bidrager som ét aspekt af en bred vifte til bedre at forstå børns oplevelse af deres verden og deres væren i denne.

\section{Fravær af det ekstraordinære}

Når man arbejder med børn, er det essentielt at være bevidst om barnets abstraktionsniveau. Hvad kan barnet rent udviklingsmæssigt overhovedet forventes at være i stand til at opleve, føle og observere på forskellige alderstrin? Der eksisterer en velfunderet udviklingspsykologisk litteratur, der fokuserer på, hvordan børns repræsentationer varierer fra et udviklingsstadie til et andet (Piaget, 1929; Vygotsky, 1978). Menneskets abstraktionsevne udvikles over tid, og mindre børn er i høj grad konkret tænkende og lidt reflekterende. Det sætter store begrænsninger for børneinterviewet og de betydningsmættede beretninger, man kan forvente, børn kan give. Støttet af tegningerne blev nye aspekter tydelige for mig, fordi tegningen kunne hjælpe med at konkretisere abstrakte tematikker, som ikke på samme måde var kommet frem i de forudgående interviews med børnene.

I forbindelse med tilblivelsen af en tegning er det i sagens natur interessant, hvad det rent faktisk er, som figurerer på papiret, og hvad det var, informanten ville tegne. Men samtidigt med at stor opmærksomhed gives til det fremstillede, er det ligeledes værd at lægge mærke til det, som ikke er med på tegningen, til det som er fraværende (Frith, Riley, Archer, \& Gleeson, 2005). På børneinformanternes tegninger af den gode familiesituation er der et påfaldende fravær af det ekstraordinære. Rubow beskriver i Samtalen, hvordan et åbenlyst fravær af et tema i en fortælling kan føre en på et analytisk spor og anspore til at lede efter 
fraværets omrids og til at få dette belyst analytisk (Rubow, 2003). Rubow tager udgangspunkt i interviewmateriale, men vores empiri viser, at det samme gør sig gældende for tegninger. Fraværet af det ekstraordinære er således med til at få den gennemgående længsel efter struktur, faste rammer og normalitet, som børnene udtrykker i deres billeder, til at træde endnu tydeligere frem og til at lede analysen på sporet af, hvordan familielivet opleves fra børnehøjde i socioøkonomisk udsatte familier med en multisyg forældre.

Studiet er ikke det første af sin slags, hvor følelsen af normalitet og hverdagsliv bliver fremhævet, som bedst tænkelige scenarier for udsatte børn og unge. Werner og Malterud udgav i 2017 en artikel, der undersøgte voksne børn af alkoholikere's tilbageblik på, hvordan de under deres barndom havde oplevet uformel støtte fra voksne med henblik på at forstå, hvordan sundhedsprofessionelle bedst muligt kan kopiere de gode situationer (Werner \& Malterud, 2017). Deltagerne fremhævede bl.a. 'safe harbours', hvor de kunne glemme turbulensen derhjemme og opleve følelsen af normalitet, som helt afgørende. Ligesom børneinformanterne i vores studie fremhæver de hverdagssituationer - den daglige rutine ved en bedstemor, at lege $i$ haven ved en ven eller at deltage i et middagsmåltid ved naboen - som situationer, der for en stund gav dem lov til at glemme deres problemer og i stedet gav dem følelsen af normalitet og stabilitet.

\section{Begrænsninger ved metoden}

Vores resultater kan være influeret af metodebegrænsninger, herunder rapporteringsbias og risikoen for at tegningerne forestiller stereotyper og normative repræsentationer (Campbell, Skovdal, Mupambireyi, \& Gregson, 2010). Ligeledes kan børnene have skildret, hvad de mente, jeg forventede, de tegnede og fortalte om (Einarsdottir et al., 2009), og børnene kan også have været påvirket og inspireret af hinandens tegninger, i og med at alle på nær en lavede øvelsen i selskab med andre børn. På trods af disse begrænsninger stemmer de fund, som vi opnåede gennem anvendelsen af metoden, overens med tidligere studier, der på samme måde har undersøgt børns oplevelse af at vokse op i en ressourcesvag familie (Fjone, Ytterhus, \& Almvik, 2009; Werner \& Malterud, 2016).

Et andet kritikpunkt i forhold til visuelle metoder handler om disse som værende særligt børnecentrerede, og hvorvidt forskning med børn virkelig er iboende anderledes end forskning med voksne (Punch, 2002). Ved at påstå at visuelle metoder per se skulle være særligt relevante at anvende i forskningsarbejde med 
børn, risikerer man at placere alle børn i én kategori og derved underkende gruppens interne diversitet. I tråd hermed var det ikke alle mine børneinformanter, som brød sig om tegneøvelsen.

Endelig har forskere sat kritisk spørgsmålstegn ved, om visuelle metoder virkelig giver mere viden end det traditionelle interview (Bagnoli, 2009). Spørgsmålet, om hvad visuelle metoder tilføjer, udspringer fra en debat om, hvorvidt forskellige metoder genererer ny viden om et undersøgt fænomen, eller om det i højere grad handler om at se på fænomenet gennem 'nye briller'. Denne debat relaterer sig til grundlæggende diskussioner indenfor mixed methods-forskning, nemlig hvorvidt det i det hele taget er muligt at integrere data indsamlet gennem forskellige metoder, og hvornår i processen disse i så fald skal 'mikses' (Mason, 2006).

Slutteligt handler metodiske bekymringer ved en visuel tilgang om etik og inkluderer emner, der peger på afsløring af private forhold og anonymitet (Moss, 2001). Kan tegning fx komme til at afsløre aspekter af informantens livsverden, som barnet egentlig ikke havde lyst til at dele, og er det derfor, det ikke bliver viderebragt $\mathrm{i}$ interviewsituationen? Som beskrevet oplevede vi én gang under øvelsen, at en lille dreng blev meget ked af det. Det ledte til overvejelser om, hvorvidt metoden havde overskredet barnets grænser, og om den, fordi den minder om legesituationer, som barnet genkender fra sin hverdag, overtrumfer barnets eventuelle forbehold.

\section{Konklusion}

Børn er - ligesom voksne - forskellige, så mens nogle datagenereringsmetoder passer rigtig godt til barnet, du sidder over for, er andre metoder måske bedre egnet til barnet, der sidder ved siden af. Det er derfor altid givende at benytte forskellige metoder i en dataindsamlingsproces. Det gælder ikke mindst i projekter som dette, hvor problemstillingerne er komplekse, og mange faktorer er i spil.

Tegning kombineret med samtale i projekter med børn kan give afsæt til at tale om tunge og svære emner, som fx børns oplevelse af en hverdag med forældres sygdom eller splittede følelse i forbindelse med familiekonflikter.

Tegning fungerer imidlertid ikke som et 'magic tool', der på mystisk vis kan åbne for en sort boks med ellers utilgængeligt data. Tegninger skal derimod altid analyseres og forstås i sammenhæng med anden indsamlet data og med afsæt i et velfunderet kontekstkendskab. 
Projektets feltarbejde bød på en hverdag i nær kontakt med børn og familier, der i perioder havde det rigtig hårdt. Det påvirker dig som menneske og som forsker og nødvendiggør, at du hele tiden forholder dig reflekterende og kritisk til det undersøgte, de metoder du anvender og de fortolkninger, du foretager.

Artiklens resultater er relevante for forskere, der ønsker at tage afsæt i et barneperspektiv i deres forskning, såvel som praktikere der arbejder med børn, og hvis arbejde afhænger af et godt indblik i børnenes erfaringer og livsverden.

\section{Illustration}

1) Hvor mon jeg skal være næste weekend?

Billede tegnet af Simone 7 år. 
2) Forestillingen om samværet med en voldelig far fra en 9-årigs perspektiv

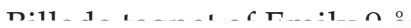

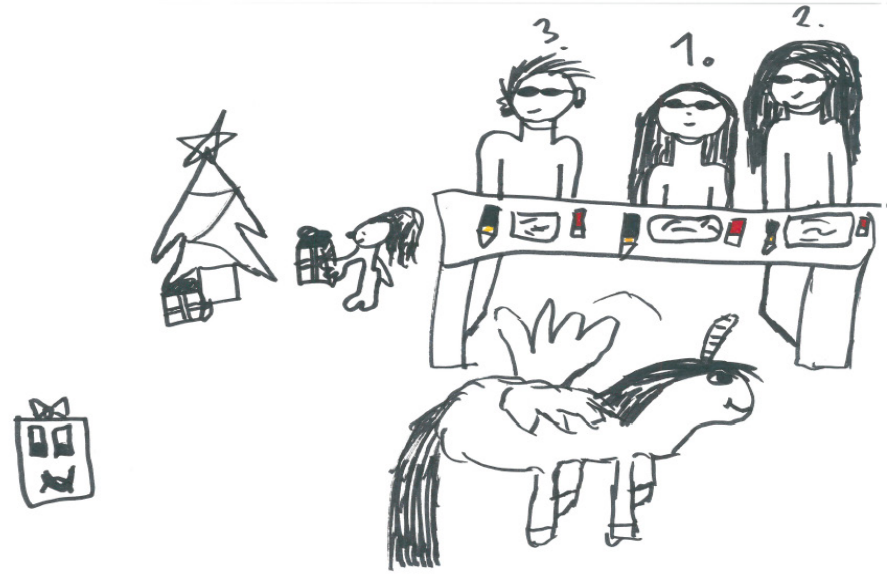

3) Ikke alle børn synes, det er sjovt at tegne

Billede tegnet af Marc 9 år.

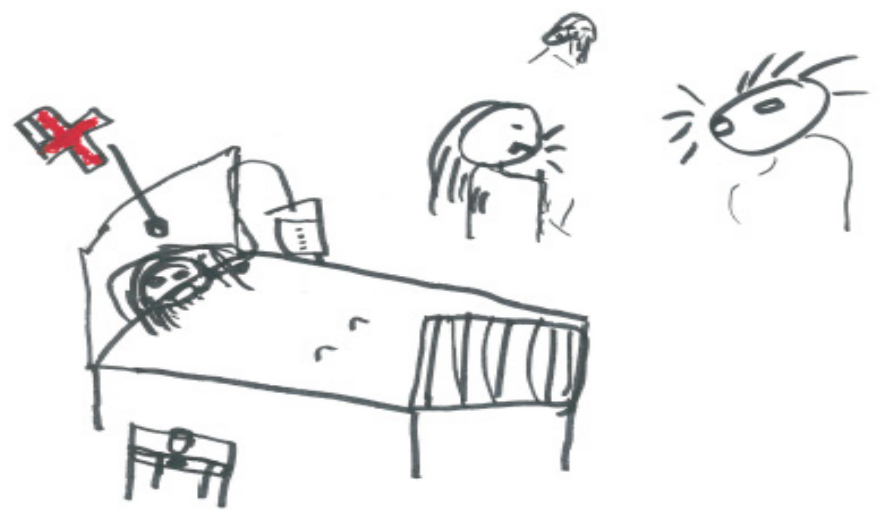




\section{4) Tolkning af tegninger kræver et velfunderet kontekstindblik for at undgå fejlfortolkning}

Billede tegnet af Julie 9 år.
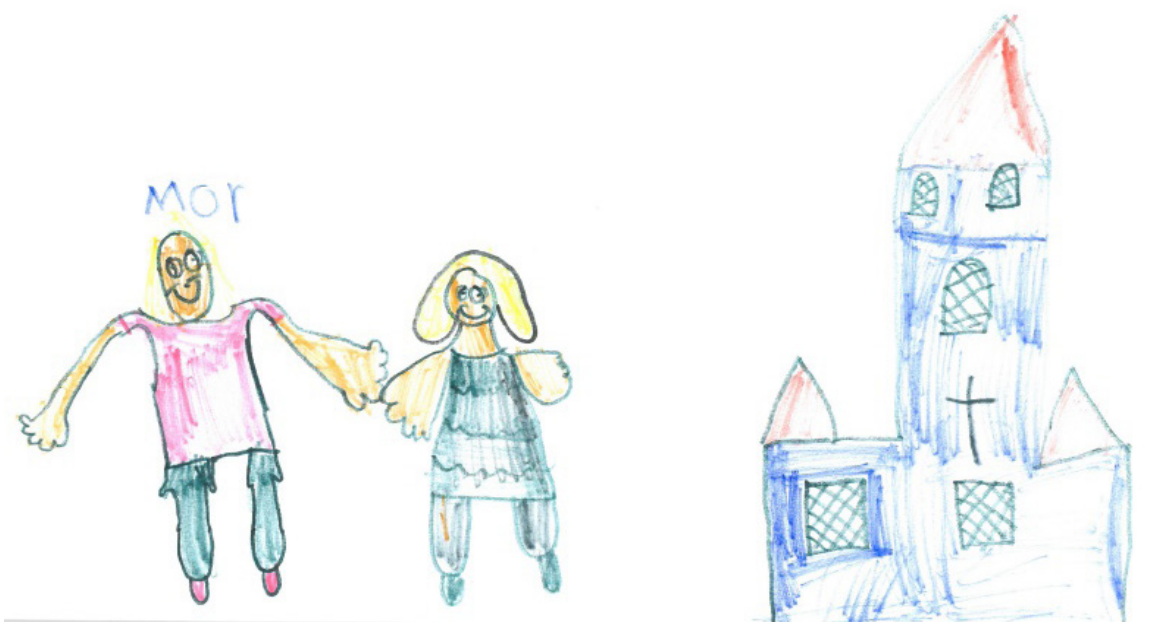

\section{Referencer}

Alderson, P. (1995). Listening to Children. Children, Ethics and Social Reseach. Barkingside: Barnardos.

Anda, R. F., Felitti, V. J., Bremner, J. D., Walker, J. D., Whitfield, C., Perry, B. D., Giles, W. $H$. (2006). The enduring effects of abuse and related adverse experiences in childhood: A convergence of evidence from neurobiology and epidemiology. European archives of psychiatry and clinical neuroscience, 256(3), 174-186. doi:10.1007/s00406-005-0624-4

Bagnoli, A. (2009). Beyond the standard interview: the use of graphic elicitation and artsbased methods. Qualitative Research, 9(5), 547-570. doi:10.1177/1468794109343625

Barker, J., \& Weller, S. (2003). »Is it fun?« developing children centred research methods. International Journal of Sociology and Social Policy, 23(1/2), 33-58. doi:10.1108/01443330310790435

Bastrup-Madsen, L. (2001). En dreng, der ikke må leve. In P. Skogemann (Ed.), Symbol, analyse, virkelighed. København: Lindhardt \& Ringhof.

Bruselius-Jensen, M. (2011). Poetiske perspektiver på det gode skolemåltid: Børns muligheder som medskabere af skolens måltider. Ph.d.-afhandling, Roskilde Universitet.

Burawoy, M. (1998). The Extended Case Method. Sociological Theory, 16(1), 4-33. doi:10.1111/0735-2751.00040

Butler, S., Gross, J., \& Hayne, H. (1995). The Effect of Drawing on Memory Performance in Young Children. Dev Psychol, 31(4), 597-608. https://doi.org/10.1037/0012-1649.31.4.597

Campbell, C., Skovdal, M., Mupambireyi, Z., \& Gregson, S. (2010). Exploring children's stigmatisation of AIDS-affected children in Zimbabwe through drawings and stories. Social Science E Medicine (1982), 71(5), 975-985. doi:10.1016/j.socscimed.2010.05.028 
Campo, J. V., Bridge, J., Lucas, A., Savorelli, S., Walker, L., Di Lorenzo, C., Brent, D. A. (2007). Physical and emotional health of mothers of youth with functional abdominal pain. Arch Pediatr Adolesc Med, 161(2), 131-137. doi:10.1001/archpedi.161.2.131

Cherney, I. D., Seiwert, C., Dickey, T. M., \& Flichtbeil, J. D. (2006). Children's Drawings: A mirror to their minds. Educational Psychology, 26(1), 127-142. https://doi. org/10.1080/01443410500344167

Christensen, P., James, A. (2000). Research with Children: Perspectives and Practices. London: Falmer Press.

Christensen, P. H. (2004), Children's participation in ethnographic research: Issues of power and representation. Children E Society, 18: 165-176. doi:10.1002/chi.823

Clark, A. (2010). Transforming children's spaces: children's and adults' participation in designing learning environments. Abingdon, Oxon: Routledge.https://doi.org/10.4324/9780203857588

Clark, C. (1999). The Autodriven interview: A photographic viewfinder into children's experience. Visual Sociology, 14(1), 39-50. doi:10.1080/14725869908583801

Clifford, J., \& Marcus, G. (Eds.). (1986) . Writing culture: The poetics and politics of ethnography. Berkeley, CA: University of California Press.

Cox, M. V. (2005). The pictorial world of the child. Cambridge, UK: Cambridge University Press.

Croghan, R., Griffin, C., Hunter, J., \& Phoenix, A. (2008). Young People's Constructions of Self: Notes on the Use and Analysis of the Photo-Elicitation Methods. International Journal of Social Research Methodology, 11(4), 345-356. doi:10.1080/13645570701605707

Darbyshire, P., MacDougall, C., \& Schiller, W. (2005). Multiple methods in qualitative research with children: more insight or just more? Qualitative Research, 5(4), 417-436. doi:10.1177/1468794105056921

Denis-Ramirez, E., Sørensen, K. H., \& Skovdal, M. (2017). In the midst of a 'perfect storm': Unpacking the causes and consequences of Ebola-related stigma for children orphaned by Ebola in Sierra Leone. Children and Youth Services Review, 73, 445-453. doi:http:// dx.doi.org/10.1016/j.childyouth.2016.11.025

Diederichs C, Berger K, \& Bartels, DB. The measurement of multiple chronic diseases a systematic review on existing multimorbidity indices. J Gerontol A Biol Sci Med Sci. 2011;66:301-311 https://doi.org/10.1093/gerona/glq208

Driessnack, M., \& Furukawa, R. (2012). Arts-based data collection techniques used in child research. Journal for Specialists in Pediatric Nursing, 17(1), 3-9. doi:10.1111/j.17446155.2011.00304.x

Einarsdottir, J., Dockett, S., \& Perry, B. (2009). Making meaning: children's perspectives expressed through drawings. Early Child Development and Care, 179(2), 217-232. doi:10.1080/03004430802666999

Elo, S., \& Kyngäs, H. (2008). The qualitative content analysis process. J Adv Nurs, 62(1), 107115. doi:10.1111/j.1365-2648.2007.04569.x

Fargas Malet, M., McSherry, D., Larkin, E., \& Robinson, C. (2010). Research with children: Methodological issues and innovative techniques. Journal of Early Childhood Research, 8(2), 175-192. https://doi.org/10.1177/1476718X09345412

Fine GA, Sandstrom KL. (1988). Knowing Children: Participant Observation with Minors. Newbury Park: Sage. https://doi.org/10.4135/9781412984706 
Fjone, H. H., Ytterhus, B., \& Almvik, A. (2009). How Children with Parents Suffering from Mental Health Distress Search for 'Normality' and Avoid Stigma. Childhood, 16(4), 461477. doi:10.1177/0907568209343743

Frederiksen, M., Gundelach, P., \& Nielsen, R. S. (2014). Mixed methods-forskning. Principper og praksisser (M. Frederiksen, Gundelach, P., Nielsen, R.S. Ed.): Hans Reitzels Forlag.

Frith, H., Riley, S., Archer, L., \& Gleeson, K. (2005). Editorial. Qualitative Research in Psychology, 2(3), 187-198. doi:10.1191/1478088705qp037ed

Funch, B. S. (1996). Den rstetiske oplevelse som transcendent frnomen. Psyke \& Logos København: Dansk Psykologisk Forlag.

Gabriels, R. L., Wamboldt, M. Z., McCormick, D. R., Adams, T. L., \& McTaggart, S. R. (2000). Children's illness drawings and asthma symptom awareness. J Asthma, 37(7), 565-574. https://doi.org/10.3109/02770900009090811

Gernhardt, A., Rübeling, H., \& Keller, H. (2013). »This Is My Family«. Journal of Cross-Cultural Psychology, 44(7), 1166-1183. doi:10.1177/0022022113478658

Graham, H. (2007). Unequal Lives: Health and Socioeconomic Inequalities. Maidenhead: Open University Press.

Gross, J., Hayne, H., \& Drury, T. (2009). Drawing facilitates children's reports of factual and narrative information: implications for educational contexts. Applied Cognitive Psychology, 23(7), 953-971. doi:10.1002/acp.1518

Gulløv, E., \& Højlund, S. (2003). Feltarbejde blandt børn. Metodologi og etik i etnografisk børneforskning. København: Gyldendal.

Hammersley, M., Atkinson, P. (2007). Ethnography. Principles in practice

Harper, D. (2002). Talking about pictures: A case for photo elicitation. Visual Studies, 17(1), 13-26. doi:10.1080/14725860220137345

Hastrup, K. (1992). Det antropologiske projekt - om forbløffelse. København: Gyldendal.

Hastrup, K., Rubow, C., \& Tjørnhøj-Thomsen, T. (2011). Kulturanalyse. Kort fortalt. København: Samfundslitteratur.

James, A., Jenks, Chris, \& Prout, Alan. (1999). Den teoretiske barndom. København: Gyldendal.

Jamieson, L., Simpson, R. \& Lewis, R. (2011). Researching Families and Relationships. Reflections on Process. Palgrave: Macmillan. https://doi.org/10.1057/9780230347960

Jolley, R. (2010). Children and pictures: Drawing and understanding. Malden, MA: Wiley-Blackwell.

Kirkengen, L. (2005). Hvordan krenkede barn blir syke voksne. Oslo: Universitetsforlaget.

Koppitz, E. M. (1968). Psychological evaluation of children's human figure drawings. New York, NY: Grune \& Stratton.

Kragh-Müller, G., \& Isbell, R. (2011). Children's Perspectives on Their Everyday Lives in Child Care in Two Cultures: Denmark and the United States. Early Childhood Education Journal, 39(1), 17-27. doi:10.1007/s10643-010-0434-9

Krippendorff, K. H. (2004). Content analysis: An introduction to its methodology. Thousand Oaks, CA: Sage Publications.

La Voy, S. K., Brauch, A. A., Luxenberg, T. M., \& Nofsinger, C. C. (2001). A cross-cultural analysis from Japan and the United States. School Psychology International, 22, 53-63. https://doi.org/10.1177/0143034301221005

Lambek, M. (2011). Kinship as gift and theft: Acts of succession in Mayotte and Israel. American Ethnologist, 38(1), 2-16. doi:10.1111/j.1548-1425.2010.01288.x 
Mandell N. (1991). The least adult role in studying children. In Studying the Social Worlds of Children, Waksler F (ed.). Falmer Press: London.

Mason, J. (2006). Mixing methods in a qualitatively driven way. Qualitative Research, 6(1), 9-25. doi:10.1177/1468794106058866

Mauthner, M. (1997). Methodological aspects of collecting data from children: lessons from three research projects. Children \& Society, 11(1), 16-28. doi:10.1111/j.1099-0860.1997. tb00003.x

Mayall, B. (2000). Conversations with children: working with generational issues. In Research with Children: Perspectives and Practices, Christensen P, James A (eds). Falmer Press: London.

Maxwell, T. I. M. (2006). Researching into Some Primary School Children's Views About School: Using Personal Construct Psychology in Practice with Children on the Special Needs Register. Pastoral Care in Education, 24(1), 20-26. doi:10.1111/j.1468-0122.2006.00357.x

Mogensen, H. O., \& Olwig, K. e. (2013). Familie og slægtskab - antropologiske perspektiver. Frederiksberg: Samfundslitteratur.

Moss, G. (2001). Seeing with the camera: analysing children's photographs of literacy in the home. Journal of Research in Reading, 24(3), 279-292. doi:10.1111/1467-9817.00149

Müller, L., \& Nielsen, A. M. (1999). Krop og billede. København: Dansklærerforeningen.

Nielsen, A. (1999). Læring, udtryksformer og symbolfelter. Forskningstidsskrift fra Danmarks Lærerhøjskole, 1 (Didaktisk refleksion - i æstetiske og humanistiske fag), 89-111.

Nielsen, A. (2012). Forskeres arbejde med oplevelser af børns tegninger som forskningsmetode. Psyke \& Logos, 33, 343-360.

Peletz, M. G. (2001). Ambivalence in Kinship since the 1940's. In S. Franklin, McKinnon S (Ed.), Relative Values: Reconfiguring Kinship Studies (pp. 413-443). Durham: Duke University Press.

Piaget, J. (1929). The child's conception of the world. London: Routledge and Kegan Paul.

Pink, S. (2005). Doing visual ethnography. London: Sage.

Pollard, A., Filer, A. (1996). The Social World of Children's Learning. Cassell: London.

Punch, S. (2002). Research with Children. Childhood, 9(3), 321-341. doi:10.1177/0907568202009003005

Reventlow, S., \& Tulinius, C. (2005). The doctor as focus group moderator - shifting roles and negotiating positions in health research. Fam Pract, 22(3), 335-340. doi:10.1093/fam$\mathrm{pra} / \mathrm{cmi003}$

Rubow, C. (2003). Samtalen. Interviewet som deltagerobservation. In K. Hastrup (Ed.), Ind $i$ Verden. København: Hans Reitzels Forlag.

Socialstyrelsen (2018). Strategisk ramme \& Faglig retning - omlægning til en tidligere forebyggende indsats,

Sommer, D., Pramling Samuelsson, I., \& Hundeide, K. (2010). Child Perspectives and Children's Perspectives in Theory and Practice (Vol. 2). New York Springer Science+Business Media B.V.

Stafstrom, C. E., Goldenholz, S. R., \& Dulli, D. A. (2005). Serial Headache Drawings by Children With Migraine: Correlation With Clinical Headache Status. Journal of Child Neurology, 20(10), 809-813. doi:10.1177/08830738050200100501

Søndergaard, D. M. (2013). Virtual materiality, potentiality and subjectivity: How do we conceptualize real-virtual interaction embodied and enacted in computer gaming, imagination and night dreams? Subjectivity, 6(S1), 55-78. doi:10.1057/sub.2012.23 
Tomasdottir, M. O., Sigurdsson, J. A., Petursson, H., Kirkengen, A. L., Krokstad, S., McEwen, B., Getz, L. (2015). Self Reported Childhood Difficulties, Adult Multimorbidity and Allostatic Load. A Cross-Sectional Analysis of the Norwegian HUNT Study. PLoS One, 10(6), e0130591. doi:10.1371/journal.pone.0130591

Vygotsky, L. S., \& Cole, M. . (1978). Mind in society: The development of higher psychological processes. London: Harvard University Press.

Wang, C., \& Burris, M. A. (1997). Photovoice: Concept, Methodology, and Use for Participatory Needs Assessment. Health Education \& Behavior, 24(3), 369-387. doi:d oi:10.1177/109019819702400309

Werner, A., \& Malterud, K. (2016). Children of parents with alcohol problems performing normality: A qualitative interview study about unmet needs for professional support. International Journal of Qualitative Studies on Health and Well-being, 11, 10.3402/qhw. v3411.30673. doi:10.3402/qhw.v11.30673

Werner, A., \& Malterud, K. (2017). How can professionals carry out recognition towards children of parents with alcohol problems? A qualitative interview study. Scand J Public Health, 45(1), 42-49. doi:10.1177/1403494816680802

Wright, S. (2007). Young children's meaning-making through drawing and 'telling': Analogies to filmic textual features. 32(Australian Journal of Early Childhood), 37-48. 